\title{
Between Theory and History: The Remains of The Day in the International Relations Classroom
}

\author{
Anthony F. Lang Jr., The American University in Cairo \\ James M. Lang, Northwestern University
}

\section{Introduction: Pedagogy, Theory, History}

Most teachers of International Relations ${ }^{1}$ have been confronted by some version of the following question, perhaps posed by a weary and skeptical student: "What use is theory? Did George Bush read Robert Keohane before seeking to use the United Nations for military actions in the Persian Gulf or Somalia?" Teachers have long struggled to explain the role that international relations theories play, both in the academy and in the policy-making world. Occasionally the links are direct; Henry Kissinger sought to put in place the realism of his theoretical writings on world politics. Yet, can we say that even a Henry Kissinger or Zbignew Brzeznski implemented a "theory" as they conducted foreign policy? And what of those theories that do not easily - or at all-lend themselves to real-world implementation, like neorealism or constructivism? Our students are often confused about the nature of the relationship between theory and history in the discipline of international relations, and their confusions can lead to severe distortions in the pictures of IR which they take from our courses.

In this article, we argue that these confusions may be, at least in part, the product of our pedagogy. This pedagogy, reflected both in introductory texts and in many syllabi, establishes a distinction between theory and practice that constructs a metaphysical division of labor between the two. For example, Charles Kegley and Eugene Wittkopf's World Politics (1995) begins with a chapter on the debate over the major contending theories of world politics. The subsequent chapters then seek to apply those theories to explain various interactions in world politics. Another text, Bruce Russet and Harvey Starr's World Politics (1992), uses the concept of a "menu" to describe international relations theories. Students see such course materials as providing a menu of IR theories, from which historical and political actors, as well as analysts and teachers, choose before acting. By relying upon this menu approach to theory, introductory courses construct the field of international relations as a set of preexisting historical facts and materials which theorists then somehow organize and interpret. ${ }^{2}$ The consequence of this approach is that most IR professors employ a pedagogical strategy that contradicts their own more sophisticated understanding of the relationship between history and theory, and between theory and practice.

In what follows we propose a solution to this problem, one that enables students to understand more accurately the role that theory plays in forming and analyzing practice. It consists of teaching a historical novel in introductory IR courses, in conjunction with a textbook and some supplementary readings. We will ground our argument by concentrating upon the use of one particular novel, Kazuo Ishiguro's The Remains of the Day (1989). Set in interwar and post-World War II Great Britain, this novel introduces students to a key historical period and raises a number of complex theoretical issues. It accomplishes both of these tasks, though, without subjecting students to staid theoretical and disciplinary debates.

We focus on two metatheoretical aspects of IR theory that can be addressed through the novel: the normative elements of IR theory and the importance of history for IR theory. Finally, we explore one particular theory that the novel helps explicate, feminism. Although we concentrate on Ishiguro's novel, other novels could serve our purposes equally well. We conclude this article with some suggestions for other novels that IR teachers might consider bringing into their classrooms. ${ }^{3}$

\section{Theory and Practice}

Some background on Ishiguro's novel may help explain why it is an excellent choice for the international relations classroom. The novel poses as the memoirs of an elderly British butler, Mr. Stevens, who is taking a motoring journey across England to visit the former housekeeper of his staff. Through the nostalgic reminiscing of this character, the reader slowly comes to realize that Stevens has served in the household of an important aristocrat, Lord Darlington, a figure who played-in the fictional world of the novel-a major role in formulating the British policy of appeasement towards the Nazis.

This Darlington, in the post-war period in which the novel is set, was publicly excoriated for these unofficial diplomatic activities, and has recently died. As Stevens travels across the country, he wrestles with the guilt he feels over his own role in helping Darlington undertake his diplomatic activities, and tries to reconcile his portrait of Darlington as benevolent employer with the postwar public vilifications of his character. Interwoven with these political and historical themes in the novel is Stevens's parallel attempt to understand how he and Darlington's former housekeeper, Miss Kenton, never were able to act upon the strong romantic feelings they had for each other.

Two particular features of the novel demonstrate some important lessons about the relationship between theory and practice: the character of Lord Darlington, and Stevens' encounter with an outspoken democrat, Harry Smith, in a small English village in which he stops for a night. The most relevant 
feature of the character of Darlington is his role as a facilitator of interaction between Nazi foreign policy officials, including the German Ambassador to Great Britain, Joachim von Ribbentrop, and selected members of the British government and aristocracy. Although Darlington had been a member of the Foreign Office (Ishiguro 1989, 72) - a common employment for young upper class males in Great Britain and elsewhere-his role as mediator between the British and German governments during the 1930's was "unofficial." But in that role, he clearly displays the hallmarks of an idealist, in the IR theoretical sense of that term; that is, Darlington believed that World War I should have convinced the world that war is pointless. As he argues at one point: "I fought that war to preserve justice in this world. As far as I understood, I wasn't taking part in a vendetta against the German race" (73). His actions throughout the novel-seeking to bring together like-minded public and private individuals, conducting diplomacy geared toward the resolution of world conflict through greater understanding and interaction, and even his concern for the poor of the Weimar Republic-reflect the thinking predominant among idealists of the interwar period (see Smith 1986; Carr 1964).

Yet, at the same time, Darlington adopts attitudes that clearly do not reflect idealist sentiments. His dismissal of democracy (Ishiguro 1989, 198 ) and his work promoting "secret diplomacy" as opposed to Wilsonian "covenants openly arrived at" are two such examples. Moreover, and more importantly, Darlington does not put his views in terms of a theory of international relations; he makes no attempts to locate his views in relation to opposing theories, and offers no discourse on what assumptions underlay his theory. The sources of his idealism appear to be threefold: a sense of noblesse oblige, his personal experience in the war, and his relationship with a German friend who dies as a consequence of the worsening economic conditions in Germany resulting from the reparations regime.

Highlighting the sources of Dar- lington's idealism teaches two important lessons to students. The first is that theory is an attempt to make sense of people's actions, which occur in the course of their daily political interactions. No political actor or theorist begins the day thinking "I will promote idealism today." Instead, people's political activities have their origins in their backgrounds, beliefs, and interactions with others. Students learn from the novel that political actions, even international political actions, result from a variety of sources, not from any single and clearly identifiable theory. Nevertheless, students can also begin to see that theory may have a role to play in the interpretation of international events. This is especially important in the case of idealism, which fifty years of realist theorists have sought to caricature as an example of misguided moralism floundering in the seas of international politics. It is difficult at times to make students understand that appeasing the Nazis did not result only from anti-Semitic leanings in British society (although these sentiments may well have existed), nor did the attempt to solve the problem of Nazi expansion by diplomacy spring from hopeless naivete about world politics. Such a policy, however formulated, was a legitimate option for educated actors of that era. The aristocratic character of Darlington allows students to conceive how such a theory might have had much greater purchase in the interwar period than it does today.

A second feature of the novel is that it provides some important insights into the value-laden character of theory. This is especially true when Stevens, the narrator, recounts his journey to a small village some twenty years after the events of the interwar period. Mistaken for a member of the nobility, Stevens finds himself the subject of a political discussion prompted by Harry Smith, one of the members of the village. Smith argues that political participation must play a role in the life of every person. Expounding on the theme of "dignity," a word Stevens had used to describe excellence in the performance of his job, Smith argues that the word could rightfully be used to explain the importance of a democratic system: "Dignity's something every man and woman in this country can strive for and get" (186). He argues that World War II was fought to preserve this dignity and democratic freedom. Stevens, encouraged by his experiences as a butler at a manor where he witnessed the wisest of political figures debating the "great issues" of the day, believes that Smith is incorrect to argue that ordinary people can successfully engage in politics. In fact, as his recollection of this encounter with Harry Smith progresses, it becomes clear that Stevens's views on this point have been greatly shaped by Lord Darlington, who claims that "Democracy is something for a bygone era" (198). Others in the novel echo Darlington's opposition to democracy; the doctor of the village, a former Communist and now half-hearted socialist, later confides to Stevens that everyday citizens like Smith are incapable of directing a nation, especially in the complex modern age.

In this scene, students can see that IR theories have a strong moral component. While the citizens' impromptu discussion of dignity does not reflect any single IR theory, their valuation of democracy clearly does touch directly on debates within IR theory; indeed, the proposition that democracies do not go to war has become a staple fixture in the neoliberal argument (cf. Chan 1997). Rather than accepting such propositions simply as objective facts that can be tested and evaluated based on accumulated statistical evidence, students reading this scene can come to understand more easily the ethical values attached to choosing democracy as a form of governance. Moreover, the debates that take place on this issue effectively demonstrate that many individuals do not value democracy in the same way that citizens of many modern-day democracies assume they do. There are large segments of the world where this debate continues to take place, with no morally obvious answer. To understand that debates like the one between Stevens and his interlocutors wereindeed still are-a part of the political discourse in Western states can be a startling revelation to jaded inheritors of established democracies. ${ }^{4}$

Hence, the novel teaches two im- 
portant lessons about the potential conflict between theory and practice..$^{5}$ The first lesson is that theory is not used by practitioners as if it were chosen from a menu of options; actors develop what we see as theories in their daily interactions with others in the political realm, and their habits and practices are informed by multiple sources in their personal and public lives. Subsequently, theory constitutes a useful tool for interpreting the moves of individual actors in international relations. The second lesson is that theory construction is not an amoral exercise in observation and hypothesis testing - it involves a series of contextualized political and moral choices about the best ways in which to conduct politics, even on the international level.

These lessons are often lost-or, worse, distorted beyond recognition-in many introductions to IR theory, but learning them is essential if students are to understand the role theory plays in the intellectual lives of political actors. Learning these lessons can also help students recognize the value theories have as tools for getting a handle on complex and potentially dishearteningbecause so seemingly diffuse-bundles of ideas, events, and individuals. As such, on a larger scale, they should help our students develop a critical reflectiveness regarding the politics they see in the news and practice in their lives, and a capacity to draw upon theoretical models and insights as they do so.

\section{History}

The second important lesson which Ishiguro's novel offers to our students is the centrality of history (the past) and historical narratives (our constructions of the past) in our understanding of international politics. History obviously plays a fundamental role in the study of international politics, but the ways in which students and professors use history is often questionable; in fact, the very idea of "using" history perhaps lies at the root of many of these confusions. Students-following their professors - often see history as a set of case studies or statis- tical tables that can be deployed to prove various hypotheses concerning world politics. While this perception may reflect the view of some of the harder positivists among us, both positivist and interpretive IR professors do need to introduce students to the complexities and potential conflicts that we-social scientists, historians, students-experience as we construct and encounter historical accounts.

The Remains of the Day provides some insight into a number of interesting historiographical debates (Lang 1997). Two of these are particularly relevant for teachers of international relations. First, the novel demonstrates that history is not simply a repository of facts, but instead a politically charged and ongoing process of presenting certain events and persons in light of divergent national interests. Second, it accurately lays bare some complex assumptions that underlie the construction of causal historical narratives.

These two issues are inextricably intertwined. Almost every historical analysis or account will include some set of causal movements-e.g., higher taxes caused the revolution, the revolution led to the rise of the dictator, etc. But those causal constructions are never simple facts, easily extractable from a pure chronicle of historical events. Instead, they are human contrivances which historians construct and deploy to make sense of the situations, events, and individuals they encounter. Consequently, those causal narratives almost invariably reflect the interests, on some level, of the historians involved.

Students immersed in the study of international politics will quickly recognize that world history presents them with a series of conflicting narratives of various key historical events. The most easily understandable illustration of this for students emerges when they are presented with the conflicting historical versions, from involved participants or interested chroniclers, of an important international event or conflict, like the events leading to the outbreak of World War I.

In these competing historical accounts each participant presents his or her own version of events, all of which must be assessed and evaluated in order to understand the negotiations as a whole. No one account can stand as the objective historical truth (if such an animal exists), largely because the conflicting theories or perspectives which fuel these events persist through the process of historicizing them-and, consequently, invest the memoirs of participants with their interesting, but potentially distorting, highlights.

The presence of such conflicts in the practice of historiography, which faculty take for granted, comes as something of a surprise to many students, who are accustomed to seeing history as a stable and inherited narrative about the past. Developmental psychologist William Perry (1970), in a classic account of student intellectual development, argued that many students begin their college years with an understanding of knowledge as "received." Such students see our disciplines as stable repositories of ideas, facts, and theories; they have no sense or knowledge of our disciplines as contested fields upon which competing accounts and claims are engaged in constant dialogue. An essential and overarching task for as teachers, whatever the discipline or level, should always be to help stu dents move beyond their initially simple conceptions of knowledge and academic study. Presenting them with these kinds of fundamental disagreements in the telling of history can be an important step in that direction. ${ }^{6}$

Ishiguro's novel, falling within the genre of historical fiction, accomplishes this task subtly and intelligently. It raises some of these historiographical questions by placing historical figures in fictional contexts, forcing students to understand the tight connections between our understanding of the past and the sense-making, but potentially distorting, mechanisms of historical narratives. Conflicts in Ishiguro's novel between "the facts" and the narratives in which those facts are embedded arise in numerous contexts, the most important of which is Stevens's first person narration. As the story progresses, the reader realizes that Stevens cannot always be trusted. Indeed, the author is quite adept at revealing this to us through Stevens's 
own stumbles in offering his explanations of the events depicted in the novel, especially those of a political nature.

As the novel progresses, the reader gradually comes to doubt the veracity of Stevens's glowing appraisals of Lord Darlington's life and character, since he inadvertently reveals certain disturbing facts about Darlington's political activities. Perhaps the most damning of these revelations is Darlington's association with Oswald Mosely, the leader of the British fascist Black Shirts movement in the interwar period. Stevens blames this association on Darlington's relationship with third parties, but we are led to believe-again, only through indirection-that Mosely did shape some of Darlington's political views. It certainly contributed to his ill-conceived and abhorrent decision to dismiss Jewish members of the household staff in order to placate visiting Nazi dignitaries (Ishiguro 1989, 145-47).

These instabilities in Stevens' narrative reflect his self-interested desire to present both himself and geard Darlington in the most favorwole light possible. Without losing starht of the fact that this text is a historical fiction, we can allow this novel to help our students see similarities between Stevens's self-interested narrative strategies and the memoirs or recollections of actors in real historical events. Again, the point here is not to suggest that historical memoirs have no more accuracy than historical fictions; it is, rather, to call students' attention to the features and narrative strategies of historical memoirs towards which they may need to cast a critical eye.

But more provocatively, the historical lesson this novel can teach our students grows out of Stevens's challenges to public history's accounting of Great Britain as a staunch opponent of Nazism. On a simple level, Stevens's act of noting the existence of the British fascist association immediately challenges that narrative construction. More significant challenges emerge from his descriptions of Darlington's meetings with Ribbentrop. Seeking to defend the honor of Lord Darlington, Stevens presents Darlington's meetings with Ribbentrop and other members of the Nazi regime as efforts to bring about world peace. Moreover, Stevens testily explains at one point, Darlington was not the only British aristocrat or diplomat whom Ribbentrop visited during this period: "The truth is that Herr Ribbentrop was, throughout the thirties, a well-regarded figure, even a glamorous one, in the very best houses" (136). Illustrating to students that the Nazis were not seen initially as the inhuman monsters which their subsequent policies and actions revealed them to be, but as legitimate representatives of an unjustly treated government, can provide a valuable lesson regarding the vicissitudes of world history. It helps us resist the insidious historiographic practice which Michael Andre Bernstein (1984) has labeled "backshadowing": judging historical actors (like the formulators of the appeasement policy) according to events in their futures which they could not have possibly foreseen (i.e., the Holocaust).

When faculty impart these kinds of historical lessons to students, the students can begin to understand that history is written with a purpose in mind-often a moral purposethat will remain invariably hidden to those who view it as a repository of data useful for testing theories. Stevens expresses doubts about his own personal powers of recollection, and in those episodes we learn to distrust his "historical account." But Stevens's historical account also helps readers to recoup certain elements of Britain's relationship to Nazi Germany which public historical accounts have had apparent difficulty in recollecting. By highlighting these lapses and corrections we can help our students recognize the double-edged sword of the historical memoir, with its mix of useful insights and self-serving distortions. We can step from this lesson, for our more discerning students, to the lesson that all historical accounts may contain their share of each of these elements.

The second useful historiographical insight to be gained from Ishiguro's novel concerns the issue of causality in historical accounts. Throughout his narrative, Stevens returns repeatedly to the question of "turning points" in his career and in his private life, seeking to identify those moments when his life underwent a radically important change. For example, one prominent theme in the novel is Stevens's inability to express his supressed feelings for Miss Kenton, the one-time housekeeper of Darlington Manor. Interspersed with his analyses of world history and politics are Stevens's attempts to understand why he never was able to voice his sentiments towards Miss Kenton, and why she left the household to marry another man despite her apparently reciprocal feelings for him. In one important passage, in which he is trying to impart some sense to the slow disintegration of his relationship with Ms. Kenton, he suspects for a moment that he has discovered the "turning point" in their relationship. He immediately questions that judgment by calling into question his ability to find a direct causal connection between any single event and his gradual estrangement from Miss Kenton:

But then, I suppose, when with the benefit of hindsight one begins to search one's past for such turning points, one is apt to start seeing them everywhere. Not only my decision in respect of our evening meetings, but also that episode in my pantry, if one felt so inclined, could be seen as such a "turning point." (176)

In this passage, as one of us has argued elsewhere, Stevens is self-consciously wrestling with one of the most fundamental questions of historiography: How can historians identify, or construct, causal seams in history (Lang 1997)? Do "turning points," such as the assassination of the Archduke Ferdinand just prior to the onset of the first World War, actually cause the events which follow? Or do such turning points exist only in our retrospective accounts of the past?

The task of understanding causality in historical narratives is central to an informed appreciation of world politics. IR theory is fundamentally about generalizations, generalizations that rely on some notion of causality. Both interpretivist and positivist theories of IR seek to find points at which events can plausibly be connected in some causal sequence. The difficulties 
Stevens has in identifying those causal sequences in his own life can be broadened to illustrate like difficulties in world history. How could anyone know-and how can anyone say for certain even nowthat the assassination of Archduke Franz Ferdinand would lead to the outbreak of World War I? Or that the U. S. Ambassador to Iraq, April Glaspie, might have inadvertently encouraged Saddam Hussein's decision to invade Kuwait by claiming that the U.S. was not interested in Arab border disputes? How these particular events become the points at which history is "made" is a highly complex, and politically charged, process. The blame placed on Glaspie for her remarks to Hussein, for example, has been interpreted by some as an attempt to discredit women in the field of diplomacy and by others as an attempt to discredit the "Arabists" in the State Department (Kaplan 1993). Whatever its source, the decision to put the responsibility on Glaspie, rather than on the Bush administration that had been supporting Hussein in his war against Iran, is a good illustration of the complex moral and political issues involved in constructing a causal pattern in world politics.

Historiographical debates may seem only marginally relevant to IR. As this novel demonstrates, however, such issues are central for understanding world politics. By using a historical novel, teachers can demonstrate to students that while history is decidedly not fiction, the similarities in the sense-making and constructive mechanisms of historical and fictional narratives (i.e., identifying heroes, constructing plots, soliciting the empathy of readers for the "characters") may be closer than students or teachers might always be willing to admit.

\section{IR as Private Practice}

The previous two sections dealt with larger theoretical issues that can be effectively conveyed to students through a directed reading of Ishiguro's novel. This section dovetails onto a slightly more specific issue, the practice of diplomacy, and demonstrates how it may be explored through the use of this novel. In particular, we want to consider how Ishiguro's novel can be used to introduce students to Cynthia Enloe's theories on the gendered assumptions underlying the practice of diplomacy. One of the central tenets of feminist IR theory is that private practices make up a key element in international politics. Ishiguro's novel illustrates this well without invoking common student resistance to any link between feminism and the supposedly nongendered realms of foreign and military policy. Helping students recognize that much of the language and action within the world of international politics is replete with gendered assumptions is a task greatly facilitated by a close inspection of the diplomacy that occurs within Darlington Manor.

As most IR teachers well know, feminist IR theorists have sought to identify the gendered assumptions underlying much of the discourse in international politics, both at the policy and academic level. ${ }^{7}$ Cynthia Enloe has demonstrated this element of world politics in less exclusively theoretical language than some other researchers, focusing instead on the practices of world politics. She has explored militarization in the UN, tourism, and diplomacy as reinforcing and relying on gender tropes. Her work on diplomacy is most relevant here. In a chapter entitled "Diplomatic Wives," Enloe (1990) explores the role the diplomatic wife plays in the everyday practices of world politics. She demonstrates that diplomacy succeeds not because of what happens at formal conferences and official meetings, but instead because of what transpires at the private gatherings and informal functions that make up a large part of the diplomat's life. Those private gatherings have traditionally been hosted by the diplomat's wife, who is consequently judged on her ability to provide an atmosphere conducive to productive interaction. In fact, a diplomat's promotion in many countries has often been based not only upon an evaluation of him, but of his wife.

How is this treated in Ishiguro's novel? Instead of a wife providing an atmosphere of comfort for the success of diplomacy, in The Remains of the Day a domestic servant plays that role. Stevens takes great pride in his ability to contribute to the success of his employer's diplomatic activities. He repeatedly emphasizes to his staff that "What happens in this house ... may have considerable repercussions," and that "History could well be made under this roof" (Ishiguro 1989, 62, 77). Yet, in the course of successfully discharging his duties, Stevens must sacrifice his personal life. On two separate occasions he must ignore the two most important people in his life, his father and Miss Kenton, for the sake of "world events." As his father lays dying, Stevens refuses to relinquish his role as the guarantor of comfort in the house, treating the foot sores of a French diplomat instead of going to his father's bedside.

The novel reveals both the positive and negative elements of this aspect of diplomacy. Stevens stresses that the best diplomacy takes place in the "privacy and calm of the great houses of this country" (115). Yet, the book also demonstrates how class- and gender-based conceptions of diplomacy tend to remove it from the democratic norms of governance. During one late-night informal diplomatic session, for example, two high-level British officials, guests of Lord Darlington, call Stevens into the room and prod him mercilessly for his opinion upon issues like the gold standard. As Stevens gently deflects their questions, humiliated but unwilling to remove himself from the room, the gentlemen triumphantly proclaim the faults of democracy, a system which would place legislative power in the hands of untutored servants like Stevens.

Moreover, the novel addresses rather directly the gendered discourse of diplomacy. As Stevens observes the attempts of the participants in the international conference hosted at Darlington Hall to maintain an informal and friendly atmosphere, he points out that the drawing room is "a rather feminine room crammed full of so many stern darkjacketed gentlemen" (92). As the gendered terms of this contrast indicate, diplomacy is a practice in which men engage in order to pro- 
tect successfully their nation's interests, a practice that does not coexist well with "feminine" concerns-despite the fact that those concerns underlay much of the successful conduct of that diplomacy.

A compelling feature of Ishiguro's novel, read with such purposes in mind, is that it allows the students to engage feminist theory without setting off the alarm bells that often sound in response to the term "feminism." Students may not so easily dismiss feminist theorizing when they can be introduced to it through a male character-one who occupies a traditionally feminine role in the world of diplomacy. By reading the novel and discussing these issues generally in the first part of the course and then exploring actual feminist texts later in the course, students can more readily see the relevance of feminist theory to the study of IR.

\section{Conclusion: Some Alternatives to Ishiguro}

Several other novels can be used to accomplish some of the same objectives The Remains of the Day helps us to accomplish. We should note, though, that Ishiguro's novel not only serves well in teaching the fundamental points we have outlined. It is particularly valuable for students of international relations because much of it is set in the interwar period in Great Britain. As is well known, IR began as a discipline roughly in this period (with the establishment of the first chair in international relations at the University of Aberystwyth in 1919), and the novel's setting in that historical moment helps contextualize two of the major wars of the international system, World Wars I and II. Moreover, the conflict in the novel revolves around matters of diplomacy, war, political responsibility, and intercultural communication. And it succeeds in imparting much of this context without losing any of its best qualities as a novel: carefully sculpted literary writing, complex and engaging characters, and a compelling set of underlying philosophical themes.

The works of British novelist
Salman Rushdie, especially Midnight's Children, address some of the same issues as Ishiguro's novel, and might serve equally well to draw the attention of IR students to the complexities of historicizing and theorizing the practices of international relations. The narrator of Midnight's Children is born at the precise moment when India becomes an independent nation, and the novel chronicles his encounters with the major political and historical figures who played a role in the early period of Indian independence, especially during the difficult and violent partitioning of Pakistan. The novel's flirtations with fantasy, though, and its deliberate play with the historical record (the fictional narrator, for example, claims responsibility for the death of Nehru and the language riots in India), might warrant some extra caution here. The actual situation of Salman Rushdie as a writer sentenced to death by the Iranian government for his distortions of historical and religious orthodoxies may offer some additionally fruitful material for consideration.

Books explicitly dealing with conflict and war can also be used fruitfully as supplementary IR texts. A literary classic like Erich Maria $\mathrm{Re}$ marque's All Quiet on the Western Front raises a number of complex issues about the relationship between international diplomacy, military conflicts, and the fates of the actual participants in those conflict. Especially interesting in the case of Remarque's novel is the fact that its incredible popularity in America in the late 1920 's and early 1930's may have contributed to broad American support for the Neutrality Acts. ${ }^{8}$ For more recent fictional appraisals of World War I, one might consider the recently completed Ghost Road trilogy of British novelist Pat Barker. Barker's novels, alternatively set in the trenches and in a British psychiatric war hospital, address issues of history, of the public's role in the decision to enter and sustain a war, and of the impact of the war on its soldiers. We look forward to hearing suggestions from other IR teachers on novels which might work equally well in the IR classroom.

\section{Notes}

1. International relations refers both to world politics and the discipline that seeks to study those political interactions. The discipline will be referred to as IR throughout this article.

2. We do not wish to single out these two textbooks-in fact, both are good introductory textbooks which one of us has used in previous classes. They do, however, reflect the problem that we are raising here-the divide between theory and practice as reflected in the presentation of material. Our point is not that some textbooks should be excised, but that all textbooks can be supplemented.

3. One alternative we would not advocate, however, would be showing the film version of Ishiguro's novel. While the movie touches on some of the ideas we discuss here, it focuses more on the novel's romantic plot-the unconsummated passion between Stevens and Miss Kenton. It offers a diluted rendering of the historical and political issues we see as the more significant elements of the novel.

4. One of us has taught this novel in an IR course at The American University in Cairo, and this point was especially evident in the discussions of this scene. While many students were angered by Darlington's dismissal of democracy, others were quite amenable to it, arguing that poor people simply do not have the intelligence to comprehend foreign affairs. Forcing students to articulate and defend their contending views was a valuable pedagogical exercise.

5. Other characters and scenes in the novel can be used to demonstrate various aspects of IR theory-the American senator Lewis, for example, embodies a version of realism that is distinctly immoral, raising questions about the values underlying this popular IR theory.

6. A cautionary note. In Perry's model, students move from an understanding of knowledge as as a set of received truths to a conception of knowledge as a collection of subjective opinions. In the subjective stage, a transitional one, students believe that there are no facts at all. The subjective stage should yield to the third and fourth stages, in which students recognize procedures for the construction and affirmation of knowledge, and see that we must make commitments to our beliefs and measure their validity using accepted procedures. Too much emphasis on the "fictionality" of historiography may keep students at the subjective stage; the instructor must point out that there are well-established methods for verifying historical evidence and constructing historical accounts.

7. For more thorough introductions to feminist IR scholarship, see Peterson (1992),

Tickner (1992), and Enloe (1993).

8. Our thanks for this suggestion, and for comments on an earlier draft of this essay, to Ken Bain.

\section{References}

Bernstein, Michael Andre. 1994. Foregone Conclusions: Against Apocalyptic History. Berkeley: University of California Press. 
Carr, E. H. 1964. The Twenty Years' Crisis, 1919-1939: An Introduction to the Study of International Relations. New York: Harper and Row Publishers.

Chan, Steve. 1997. "In Search of Democratic Peace: Problems and Promise." Mershon International Studies Review 41 (Suppl. 1): 59-92.

Enloe, Cynthia. 1990. Bananas, Beaches and Bases: Making Feminist Sense of International Politics. Berkeley: University of California Press.

- 1993. The Morning After: Sexual Politics at the End of the Cold War. Berkeley: University of California Press.

Ishiguro, Kazuo. 1989. The Remains of the Day. New York: Vintage International.

Kaplan, Robert. 1993. The Arabists: The Romance of an American Elite. New York: The Free Press.

Kegley, Charles, and Eugene Wittkopf. 1996. World Politics: Trend and Transformation. 5th ed. New York: St. Martin's Press.

Lang, James. 1997. "Public Memory, Private Fiction: Kazuo Ishiguro's History." Northwestern University. Manuscript.
Perry, William. 1970. Forms of Intellectual and Ethical Development in the College Years: $A$ Scheme. New York: Harcourt Brace Jovanovich.

Peterson, V. Spike, ed. 1992. Gendered States: Feminist (Re) visions of International Relations Theory. Boulder: Lynne Rienner Publishers.

Russet, Bruce, and Harvey Starr. 1992. World Politics: The Menu for Choice. 4th ed. New York: W.H. Freeman.

Smith, Michael. 1986. Realist Thought from Weber to Kissinger. Baton Rouge: Louisiana State University Press.

Tickner, J. Ann. 1992. Gender in International Relations: Feminist Perspectives on Achieving Global Security. New York: Columbia University Press.

\section{About the Authors}

Anthony F. Lang Jr. is an assistant professor in the department of political science at The American University in Cairo. His work addresses international relations theory and national security, with a focus on ethics and Middle East Studies.

James M. Lang is the assistant director of the Searle Center for Teaching Excellence at Northwestern University, and teaches courses on twentieth-century fiction in Northwestern's English department. He has numerous articles, reviews, and essays published or forthcoming on twentieth-century literature and criticism (in forums such as Essays in Theater, Philosophy and Literature, and Modern Fiction Studies) as well as several articles on teaching and learning at the college and university level (in forums such as The Teaching Professor and The National Teaching and Leaming Forum). 